\title{
BLOOD VOLUME CHANGES IN ANAEMIA FOLLOWING TRANSFUSION
}

\author{
BY \\ SHEENAH J. M. RUSSELL, M.B., Ch.B. \\ (From the Royal Hospital for Sick Children, Glasgow, and the Department of Medical \\ Paediatrics, University of Glasgow)
}

Investigations by various workers from the time of Valentin (1847) to the present day have shown that the blood volume is not a constant, and that there exists a state of ' $\mathrm{ebb}$ and flow' between the plasma and the tissue fluids. The haemodilution which occurs after acute reduction of the blood volume following a haemorrhage has been observed frequently (Boycott and Douglas, 1909; Robertson and Bock, 1919; Wallace and Sharpey-Schäfer, 1941), while the converse reaction-the occurrence of fluid shifts following the transfusion of serum and blood-has also been recognized and studied (Boycott and Oakley, 1934; Sharpey-Schäfer and Wallace, 1942a; Hayward and Jordan, 1942; Beattie, 1942).

The following two cases of anaemia are reported in view of the completely different responses to blood transfusion, the one reacting by the addition of fluid to the blood stream, the other by the loss of fluid. The initial blood volumes were determined by a dye dilution method, using Congo red to determine the plasma volume, and the haematocrit readings to calculate the total blood volume. In the recent blood volume estimations Evans blue has been used, but the results agree within 10 per cent. of those obtained by Congo red. The haemoglobin values of the transfused blood, and those of the patients before and at intervals after transfusion, were estimated by an acid haematin method on a photo-electric colorimeter.

\section{Case Histories}

Case 1. J. L., aged six years, admitted October 2 , 1945, was a coeliac dwarf, 53 per cent. of expected weight and 86 per cent. of expected height. He had a severe macrocytic anaemia, which failed to respond to liver and iron. On October 4, the blood picture was as follows: Haemoglobin, 2.9 g. per cent.; erythrocytes, 990,000 per c.mm.; leucocytes, 7,000 per c.mm.; haematocrit reading, 11.3 per cent.; mean corpuscular volume, 11.4 c. $\mu$; mean corpuscular haemoglobin concentration, 26 per cent.; mean corpuscular diameter, $8 \mu$; total plasma protein, $4 \cdot 35$ g. per cent.

The total blood volume before transfusion was $843 \mathrm{c} . \mathrm{cm}$. (7.8 per cent. body weight; $74 \mathrm{c.cm}$. per $\mathrm{kg}$. of body weight; $8.9 \mathrm{c.cm}$. per $\mathrm{cm}$. of height); average values for healthy children of the same age (Congo red) being: total volume, $1,535 \mathrm{c.cm}$. (8.9 per cent. body weight; $84 \mathrm{c.cm}$. per $\mathrm{kg}$. of body weight (range 76-95 c.cm.); $13 \mathrm{c.cm}$. per cm. of height (range 11.5-15.5 c.cm.).

Blood transfusion was given on November 19, using bank blood, of which $175 \mathrm{c} . \mathrm{cm}$. had a haemoglobin of $7.01 \mathrm{~g}$. per cent. and $80 \mathrm{c.cm}$. a haemoglobin of $9.83 \mathrm{~g}$. per cent.

Case 2. J. C., aged two years three months, was admitted on November 6, 1945, with a history of increasing pallor and cervical lymph gland enlargement of three months' duration. The condition proved to be one of aleukaemic lymphatic leukaemia. He was a well-grown child, 109 per cent. of expected weight and 104 per cent. of expected height. Blood investigation on November 7 gave the following figures: Haemoglobin, 3.7 g. per cent.; erythrocytes, $1,210,000$ per c.mm.; leucocytes, 8,000 per c.mm.; haematocrit reading, 9.4 per cent.; mean corpuscular volume, 78 c. $\mu$; mean corpuscular haemoglobin concentration, 36 per cent.; mean corpuscular diameter, $7 \mu$; total plasma protein, 7.35 g. per cent.

The total blood volume before the first transfusion (November 7) was $1,147 \mathrm{c.cm}$. (8.8 per cent. body weight; $84.3 \mathrm{c.cm}$. per kg. of body weight; $13.2 \mathrm{c.cm}$. per $\mathrm{cm}$. of height); before the second transfusion (November 21) it was $1,366 \mathrm{c.cm}$. (10.9 per cent. body weight; $103.5 \mathrm{c.cm}$. per $\mathrm{kg}$. of body weight; $15.7 \mathrm{c.cm}$. per $\mathrm{cm}$. of height). The average values for healthy children of the same age group (Congo red) are: total volume, 964 c.cm. (9.3 per cent. body weight; $88 \mathrm{c.cm}$. per kg. of body weight 
(range 86-104 c.cm.); $10.9 \mathrm{c.cm}$. per cm. of height (range 10-12.5 c.cm.)).

He was transfused on two occasions: (1) November $11,230 \mathrm{c} . \mathrm{cm}$. of bank blood containing $11.6 \mathrm{~g}$. per cent. haemoglobin; (2) November $21,165 \mathrm{c.cm}$. of packed red cells, containing $15 \mathrm{~g}$. per cent. haemoglobin.

The haemoglobin values in the above two cases are given in table 1 .

TABLE 1

HAEMOGLOBIN VALUES

\begin{tabular}{|c|c|c|c|}
\hline & \multirow{2}{*}{ Case 1} & \multicolumn{2}{|c|}{ Case 2} \\
\hline 1 & & 1st transf. & 2nd transf. \\
\hline $\begin{array}{l}\text { Before transfusion } \\
5 \text { mins. after ", } \\
12 \text { hrs. after ", } \\
24 \text { " ", } \\
48 \text { Transfused blood }\end{array}$ & $\begin{array}{c}\text { g. per cent. } \\
3.40 \\
4.42 \\
3.51 \\
3.58 \\
4.34 \\
7.01 \\
(175 \text { c.cm.) } \\
+9.83 \\
\text { (80 c.cm.) }\end{array}$ & $\begin{array}{c}\text { g. per cent. } \\
1 \cdot 70 \\
3 \cdot 74 \\
\overline{4.19} \\
\overline{11.66} \\
(230 \mathrm{c.cm} .)\end{array}$ & $\begin{array}{c}\text { g. per cent. } \\
3-03 \\
6.02 \\
\overline{5.70} \\
\overline{15} \\
\text { (165 c.cm.) }\end{array}$ \\
\hline
\end{tabular}

\section{Estimation of Blood Volume}

In determining the blood volume of shocked patients before blood transfusion Hill (1941) made use of the haemoglobin values as follows:

If $\boldsymbol{x}=$ initial blood volume before transfusion

$V=$ volume of blood transfused

$\mathrm{Hb}_{\mathrm{v}}=$ haemoglobin concentration of the transfused blood

$\mathrm{Hb}_{\mathbf{1}}=$ haemoglobin concentration before transfusion

$\mathrm{Hb}_{2}=$ haemoglobin concentration after transfusion,

then, by equating the total quantities of haemoglobin,

$$
\text { Hence } \quad x=\frac{V\left(H b_{v}-H b_{2}\right)}{H b_{2}-H b_{1}} \text {. }
$$$$
x \mathrm{Hb}_{1}+\mathrm{VHb}_{\mathrm{v}}=(x+\mathrm{V}) \mathrm{Hb}_{2} \text {. }
$$

In neither of these patients did the initial blood volume (B.V.) calculated from the above formula tally with the observed blood volume determined by the Congo red method at the beginning of the experiment (table 2).

Efiect of plasma shifts. McMichael et al. (1943) pointed out that a serious source of error in the above formula was the occurrence of plasma shifts, as the red cell volume in man is constant, apart from the normal removal of effete cells and the addition of new cells from the bone marrow (Ebert and Stead, 1941). The former authors accordingly modified the formula in the following manner. If $y$ c.cm. of plasma leave the blood before the final
TABLE 2

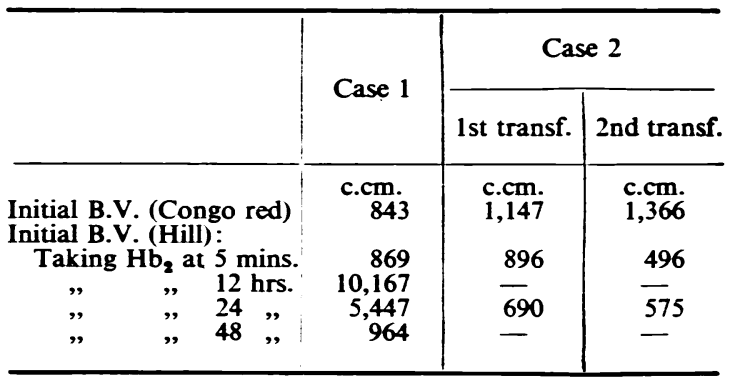

haemoglobin estimation, then, by equating the total amounts of haemoglobin,

$$
\begin{array}{cc}
x H b_{1}+V H b_{v}=(x+V-y) H b_{2} . \\
\text { Hence } x=\frac{V\left(H b_{v}-H b_{2}\right)}{H b_{2}-H b_{1}}+\frac{y H b_{2}}{H b_{2}-H B_{1}}
\end{array}
$$

If there is a shift of fluid to the circulation during transfusion, then the $y$ fraction becomes a negative quantity. It will be seen, therefore, that if fluid leaves the blood stream before the final haemoglobin estimation, the value for $x$ as calculated by Hill's formula will be too small by the value of the fraction $\frac{y \mathrm{Hb}_{2}}{\mathrm{Hb}_{2}-\mathrm{Hb}_{1}}$, while if fluid is added to the circulation $x$ will be too large by the same amount.

From the results shown above, using the original formula of Hill, the following conclusions were drawn:

1. In case 1 no significant fluid shifts took place during the transfusion. The results at 12,24 , and 48 hours, however, are obviously too high, that for 12 hours ridiculously so. Therefore it was assumed that fluid had been added to the circulation in considerable amount following the transfusion.

2. In case 2 , in both instances, fluid must have left the blood stream during the actual transfusion. After the first transfusion, fluid continued to leave up till 24 hours, while after the second a small

TABLE 3

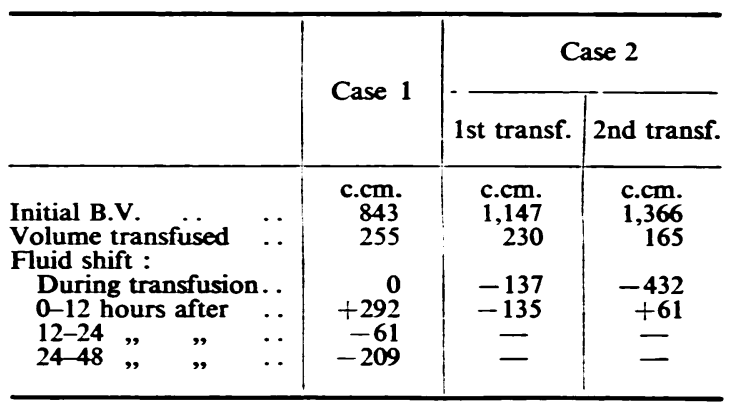

+ indicates addition of fluid to the circulation.

- indicates withdrawal of fluid from the circulation. 
amount of fluid was added to the circulation during the 24 hours ensuing.

The modified formula was then applied to calculate $y$, the amount of fluid shift, by substituting for $x$, the observed initial blood volume estimated by the dye method. The results shown in table 3 were obtained.

\section{Post-transfusion Response}

It is of interest to note the difference in posttransfusion response in these two patients, who were alike in exhibiting a very severe degree of anaemia. Two main points of contrast exist, which may help to explain the difference in reaction.

The initial state of the blood volume differed in the two cases. J. L., the coeliac dwarf with macrocytic anaemia, whose reaction during the first twelve hours was that of fluid addition to the blood, had a blood volume which was rather low when related to weight, but, when related to height, definitely below the average for his age group. As the child was only 53 per cent. of expected weight, in contrast to 86 per cent. of expected height, the height relationship forms a better basis for comparison with healthy children (Gibson and Evans, 1937). J. C., on the other hand, had an initial blood volume which was rather higher than the average-why this is so is not apparent-and the response to transfusion was that of fluid shift to the tissues, the exact opposite of what occurred in case 1 . It has been shown that, when the blood volume is at a normal level, transfused serum tends to leave the circulation within one to two hours (Sharpey-Schäfer and Wallace, 1942a). Similarly with transfusion of whole blood in chronic anaemia the added plasma may disappear even during the transfusion, particularly if the rate of giving is slow (Marriott and Kekwick, 1940).

The other factor which may explain these results is the different relationship existing in the two patients between the plasma protein levels of the blood of donor and recipient. If a patient is transfused with blood of a higher protein content than his own there is likely to be a transference of fluid from the tissues to equalize the osmotic pressures, and, conversely, a transfused blood of lower protein content would tend to cause a fluid shift to the tissues (Metcalfe, 1944). Taking an average of $6 \mathrm{~g}$. per cent. as the total protein level of bank blood, it will be seen that $J$. L. had a plasma protein level well below this (4.35 g. per cent.) and J. C. considerably above (7.35 g. per cent.).

The failure in case 1 to retain the additional fluid after $\mathbf{4 8}$ hours may be due to the fact that the added protein was rapidly withdrawn from the circulation to make good the deficiencies in the protein stores, which, considering his state of prolonged malnutrition, were probably low (Chang, 1932; Madden and Whipple, 1940; Ebert et al,, 1941; Beattie and Collard, 1942). That some of the fluid removed from the plasma as a result of transfusion may enter the red cells is demonstrated in case 2 (Dyson et al., 1944). The mean corpuscular volume and the mean corpuscular haemoglobin concentration in this case are shown in table 4.

TABLE 4

\begin{tabular}{|c|c|c|}
\hline Date & M.C.V. & M.C.HbC. \\
\hline $\begin{array}{l}\text { November } 7 \\
\quad \text { (November } 11 \text { : } \\
\text { November } 21 \\
\quad \text { (Lansfusion) } \\
\text { November } 28 \\
\text { day : }\end{array}$ & $\begin{array}{r}\text { c. } \mu \\
78 \\
114 \\
109\end{array}$ & $\begin{array}{c}\text { per cent. } \\
38 \\
23 \\
24\end{array}$ \\
\hline
\end{tabular}

In view of the recent work on the increased cardiac output and poor cardiac reserve in chronic anaemia (Sharpey-Schäfer, 1944; Hunter, 1946), and the dangers of transfusion unless by slow drip (Altschule and Gilligan, 1938; Sharpey-Schäfer, 1945), it is interesting to note that in these two patients the blood was syringed into a vein at the rate of about $5 \mathrm{c.cm}$. per minute, and that neither showed any adverse reaction. Both cases showed such extreme pallor before transfusion, however, that it may be concluded that the compensatory vasoconstriction was well marked. During the transfusion distinct flushing and heat of the skin were noted, but without venous engorgement, indicating that the dilatation of previously constricted vessels had enlarged the vascular bed sufficiently to accommodate the increased blood volume (Sharpey-Schäfer and Wallace, 1942b).

\section{Summary}

The difference in the behaviour of the blood volume following transfusion in two severely anaemic children has been studied. In one case fluid was added to the circulation; in the other it was withdrawn.

The suggestion is made that the results can be explained by the difference in the initial blood volume of the two patients, and in the plasma protein levels of the blood of the donor and recipient.

The author wishes to thank Dr. Stanley Graham for permission to study these patients, and for his advice and criticism. 
REFERENCES

Altschule, M.D., and Gilligan, D. R. (1938). J. clin. Invest., 17, 401.

Beattie, J. (1942). Brit. med. J., 1, 459.

and Collard, H. B. (1942). Ibid., 2, 507.

Boycott, A. E., and Douglas, C. G. (1909). J. Path. Bact., 13, 256.

- and Oakley, C. L. (1934). Ibid., 38, 91.

Chang, H. C. (1932). Proc. Soc. exp. Biol., N.Y., 29, 829.

Dyson, M., Plaut, G., and Vaughan, J. (1944). Quart. J. exp. Physiol., 32, 255.

Ebert, R. V., Stead, E. A., and Gibson, J. G. II. (1941). Arch. intern. Med., 68, 578.

- and Stead, E. A., jun. (1941). Amer. J. med. Sci., 201, 655.

Gibson, J. G. II., and Evans, W. A., jun. (1937). J. Valentin, G. G. (1847). Lehrbuch der Physiologie, Band clin. Invest., 16, 317.

Hayward, G. W., and Jordan, A. (1942). Brit. med. J., 1, 462.
Hill, D. K. (1941). Lancet, 1, 177.

Hunter, A. (1946). Quart. J. Med., 15, 107.

McMichael, J., Sharpey-Schäfer, E. P., Mollison, P. J., and Vaughan, J. M. (1943). Lancet, 1, 637.

Madden, S. C., and Whipple, G. H. (1940). Physiol. Rev., 20, 194.

Marriott, H. L., and Kekwick, A. (1940). Brit. med. J. 1, $1,043$.

Metcalfe, W. (1944). J. clin. Invest., 23, 403.

Robertson, O. H., and Bock, A. V. (1919). J. exp. Med., 29, 139, 155.

Sharpey-Schāfer, E. P. (1944). Clin. Sci., 5, 125.

- (1945). Lancet, 2, 296.

- - and Wallace, J. (1942a). Ibid., 1, 699. (1942b). Brit. med. J., 2, 304. 1, S. 493, Vieweg und Sohn, Braunschweig.

Wallace, J., and Sharpey-Schäfer, E. P. (1941). Lancet, 2, 393. 